Chapter 20

\title{
Allelochemicals as Bioherbicides - Present and Perspectives
}

\author{
Dorota Soltys, Urszula Krasuska, \\ Renata Bogatek and Agnieszka Gniazdowska \\ Additional information is available at the end of the chapter \\ http://dx.doi.org/10.5772/56185
}

\section{Introduction}

Since the first implementation of synthetic herbicides in crop protection systems, weeds have continuously developed resistance. As a main reason of such evolution, long-lasting exploitation of herbicides with one target site in plants is considered. This has been the case with the first widely-used triazine herbicides, photosynthesis inhibitors, which have effectively eliminated a wide range of weeds. Unfortunately, inappropriate adjustment of herbicides to weed species occupying fields, application of herbicides at the incorrect developmental stage and in unsuitable weather conditions have contributed to the accumulation of active compounds in the soil, accumulation of weed species and acceleration evolution of resistant biotypes [1]. To date, there have been 211 species and 393 biotypes of herbicide resistant weeds identified [2]. Most of them are resistant to B, C1 and A groups of herbicides, inhibitors of: acetolactate synthase (ALS), photosystem II and acetyl CoA carboxylase, respectively. Ten species pose the biggest threat for crops due to causing yield losses, including the most important herbicide-resistant species which are characterized by multiple resistances: rigid ryegrass (Lolium rigidum Gaud.), wild oat (Avena fatua L.) and redroot pigweed (Amaranthus retroflexus L.).

Evolution of weeds resistant to herbicides demands new solutions to cope with the problem since economic losses generated by weeds can be higher than those caused by other pests. Due to the fact that abandoning chemical weed control is, with current agricultural practices, rather impossible, it is necessary to create new classes of herbicides with new mechanisms of action and target sites not previously exploited. Presently used synthetic herbicides are not approved for use in organic agriculture. Moreover, using crop protection chemicals also need public acceptance. [3]. The number of synthetic chemicals with new target sites are decreasing 
dramatically. Eco-friendly trends in weed management force scientists to reach for innovative sources and tools. Natural compounds pose a great field for the discovery of new environmentally safe herbicides, so called "bioherbicides", which are based on compounds produced by living organisms. According to the CAS (Chemical Abstracts Service) registry, among the 24 million organic compounds, a large group of secondary plant metabolites is represented. Some of these compounds take part in allelopathic interactions.

\section{Allelopathic interactions and allelopathic compounds}

Allelopathy is considered a multi-dimensional phenomenon occurring constantly in natural and anthropogenic ecosystems [4]. It is defined as the interaction between plants and microorganisms by a variety of compounds usually referred to as allelopathins, allelochemicals, or allelopathic compounds. This review is focused mainly on compounds taking part in complex allelopathic interactions between higher plants. However, determination of quality, quantity, direct or indirect effects of allelopathins on plant or microorganism communities in the natural environment is very difficult owing to the multi-dimensional character of those interactions. The development of analytical techniques allowing better specification of direct effects of allelopathins, have moved the exploration (or the research on) of this phenomenon from fields into laboratories. The term "allelopathy" refers rather to interactions occurring in the natural environment [5]. For studies with plant extracts, allelopathins isolated from plant tissue, collected from exudates or even synthetic compounds identical to natural ones, it was established the term "phytotoxicity" to distinguish allelopathy (as a phenomenon occurring in natural environment) from studies conducted in laboratory.

Allelopathins are products of the secondary metabolism and are non-nutritional primary metabolites [6,7]. These compounds belong to numerous chemical groups including: triketones, terpenes, benzoquinones, coumarins, flavonoids, terpenoids, strigolactones, phenolic acids, tannins lignin, fatty acids and nonprotein aminoacids. A wide range of these biochemicals are synthesized during the shikimate pathway [8] or, in the case of essential oils, from the soprenoid pathway. Allelochemicals can be classified into 10 categories [9] according to their different structures and properties:

1. water-soluble organic acids, straight-chain alcohols, aliphatic aldehydes, and ketones;

2. simple lactones;

3. long-chain fatty acids and polyacetylenes;

4. quinines (benzoquinone, anthraquinone and complex quinines);

5. phenolics;

6. cinnamic acid and its derivatives;

7. coumarins;

8. flavonoids; 
9. tannins;

10. steroids and terpenoids (sesquiterpene lactones, diterpenes, and triterpenoids).

Allelochemicals are released into the environment by plant organs such as roots, rhizomes, leaves, stems, bark, flowers, fruits and seeds (Figure 1a). The huge number of allelopathic interactions is typically negative in character, with positive relations being rare. Allelopathic compounds affect germination and growth of neighboring plants by disruption of various physiological processes including photosynthesis, respiration, water and hormonal balance. The underlying cause of their action is mainly inhibition of enzyme activity. Ability of an allelochemical to inhibit or delay plant growth and/or seed germination is usually defined as its "allelopathic (or phytotoxic) potential". An excellent example of allelopathic interaction is seen in soil exhaustion due to the accumulation of allelopathins that can be prevented by using fertilizers and rotating crops. Plants producing allelopathins are considered as "donor" organisms while the plants which allelopathins are directed to are referred to as "target" plants or "acceptors". The after-effects and strength of allelopathic interactions are diverse due to modifications of the allelopathins taking place in soil (Fig 1b). Most of the allelochemicals penetrate the soil as already plant-active compounds, e.g. phenolic acids, cyanamide, momilactones, heliannuols etc. Some have to be modified into the active form by microorganisms or by specific environmental conditions ( $\mathrm{pH}$, moisture, temperature, light, oxygen etc.), e.g. juglone, benzoxazolin-2-one (BOA), 2-amino-3-H-phenoxazin-3-one (APO).

\section{Advantages and disadvantages of allelopathins as bioherbicides}

Mode of action of some allelochemicals is similar to synthetic herbicides. These features have allowed them to be considered for possible use in weed management as bioherbicides. However, the field of knowledge is poorly studied but it is a very attractive area to explore.

Allelochemicals are highly attractive as new classes of herbicides due to a variety of advantages. However, in the perspective of bioherbicides based on allelopathins, effects caused by these compounds on target plants are also classified as "phytotoxic".

Most of allelopathins are totally or partially water-soluble which makes them easier to apply without additional surfactants [3,10]. Their chemical structure is more environmentally friendly than synthetic ones. They possess higher oxygen- and nitrogen-rich molecules with relatively few so called 'heavy atoms', a halogen substitute, and are characterized by the absence of 'unnatural' rings. These properties decrease a chemical's environmental half-life, prevent accumulation of the compound in soil and eventual influence on non-target organisms. On the other hand, these properties are an allelochemical's Achille's heel due to less than satisfactory duration of activity. Structure complexity generates more stereocenters making them more reactive and unstable. Therefore, rapid degradation of one of the chemical groups can significantly decrease bioactivity of the whole compound.

The diversity of allelopathins makes them promising tools possessing specific properties in discovering novel, specific target sites in acceptor plants. Even if they inhibit photosynthesis 


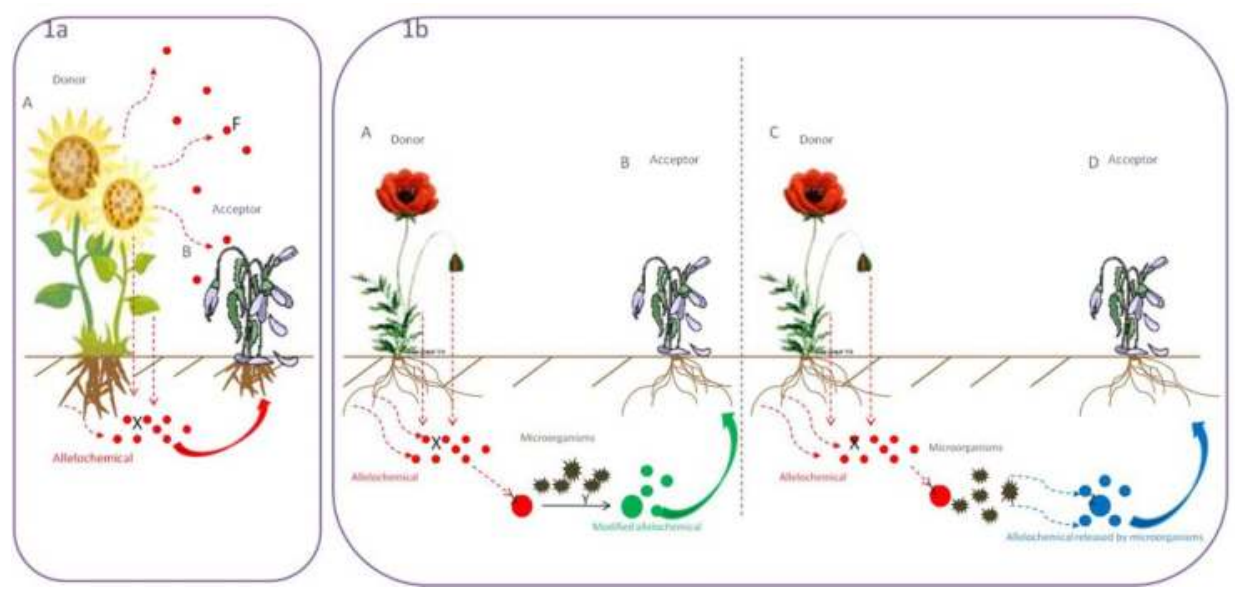

Figure 1. Multi-dimensional nature of allelopathic interacions. (1a) Plant A releases allelochemicals X and F which directly affect growth of plant $B$. (1b) left side; Plant $A$ releases allelochemical $X$ which is modified or activated by microorganisms to allelochemical $Y$ that affects growth of plant B. (1b) right side; Plant A releases allelochemical $X$ which stimulates microorganisms to produce allelochemical $Z$ that affects growth of plant $B$.

or respiration, they may also bind to proteins at different sites than synthetic herbicides [11, 12]. This provides the opportunity to eliminate weeds that are already resistant to commercialized herbicides with the same mode of action. Allelochemicals are also characterized by multi-site action in plants without high specificity which is achieved in the case of synthetic herbicides. Therefore, this feature excludes the application of an allelopathic compound as a selective herbicide or totally prohibits its usage in weed management. On the other hand, effects of allelopathins in acceptor plants are highly dose-dependent [13]. This allows the opportunity to search out compounds exhibiting selectivity. Generally, monocotyledonous plants are more resistant to allelochemicals than dicotyledonous ones. Therefore, usage of a compound as a potential herbicide is possible but rather restricted to cultivation of exact crops with a defined weed composition.

The route of discovery is much more complicated with allelopathins. In contrast to synthetic herbicides where synthesis, bioassay, evaluation and quantitative structure-active relationship follow Quantitative Structure-Activity Relationship (QSAR), allelochemicals have to be first isolated from plant extracts [14]. The amount of recovered compounds is usually low in comparison to chemical synthesis. After extraction, purification and selection of the most attractive compound and determination of its mode of action in plants is done. At the end of the process, similar to synthetic herbicides, allelpathins are subjected to QSAR. The long discovery process is usually offset by a shorter, less expensive track of registration [15]. It is worth noting that before an allelochemical can become an herbicide, the following conditions have to be performed: phytotoxic activity at the range between $10^{-5}$ and $10^{-7} \mathrm{M}$, identified chemical structure, known mode of action in plants, time of residence in soil, possible influence 
on microbial ecology and non-target plants, possible toxic properties on human health and profitability of production on a commercial scale [16].

A high number of limitations does not exclude allelochemicals as possible herbicides. In particular, they can be alternatives in weed management strategy. Widely developed bioinformatics and cheminformatics support development of new herbicides [3, 15, 16]. Identified chemical structure of a particular allelochemical is a starting point to design a product with the compound-like properties using computer programs. Thanks to cheminformatics we are able to predict the potential structure of analogues and make several modifications, which make it more or less active, with higher environmental stability, as it was done for leptospermone. We may also predict the target site of compound action in plants due to comparison studies. Similar structure of a compound to a commercialized herbicide or other natural compound whose mode of action is well-known may allow us to predict the target site.

\section{Allelopathic plant extracts as bioherbicides}

Plant protection is effective but rather costly and problematic due to environmental pollution. Exploration of the allelopathic potential of some species allows the introduction of alternative techniques for weed management, e.g. extracts from allelopathic plants can be applied as foliar sprays. Apart from decreasing the costs of herbicide application, this method also improves crop production.

The best known examples of natural bioherbicides are phytotoxic water extracts from herbage of sorghum (Sorghum bicolor (L.) Moench.) (sorgaab) and sunflower (Helianthus annuus L.) (sunfaag) which can be effectively used in plant protection without yield losses.

Effects of sorgaab on weeds is time- and dose-depend but is typically used at $5 \%$ or $10 \%$ (w/v) concentration as double spray 20/30 and 40/60 days after sowing (DAS) or after seedling transplantation (AT) [17-19]. The best results to account for net profits have been elicited with a double spray of $10 \%$ extract in cotton (Gossypim hirsutum L.), soybean (Glycine max L.), wheat (Triticum aestivum L.) or rice (Oryza sativa L.). The highest efficacy of such extract applications has been verified in rice on reduction of barnyard grass (Echinochloa cruss-galli L.) biomass by $40 \%$, without significant changes in weed density and accompanied yield increase by $18 \%$.

Sunfaag has been widely used in wheat. The extract has been usually applied three times at 7day intervals starting between 3-4 weeks post-emergence. This system of application has reduced biomass of the two most commonly occurring weeds, lambsquarters (Chenopodium album L.) and toothed dock (Rumex dentatus L.), by $70 \%$ and $97 \%$ respectively, although it has not eliminated all weed species in field. It has improved wheat biomass by $7-8 \%$ in comparison to weed free control without significant changes in number of tillers and total seed biomass. The herbicidal efficiency calculated as the effectiveness of sunfaag in comparison to synthetic herbicides showed a quite high value, $60 \%$ efficiency index. Weed management systems require high concentrations of sunfaag ranging up to $80 \%$ and can generate economic losses due to the necessity of cultivating higher amounts of sorghum or sunflower that also required 
an appropriate cultivation system [20, 21]. Therefore, sunfaag can be applied as a preemergence herbicide with much lower doses. The most promising application system has considered usage of $10 \%(\mathrm{w} / \mathrm{v})$ extract at pre-emergence + 25 DAS + 35 DAS. Following the application, there has been noted a remarkably reduced population of wild oat, lesser swinecress (Coronopus didymus L.) and littleseed canarygrass (Phalaris minor Retz.) without affecting germination of wheat and increased wheat yield in 7\% [22]. However, the inhibitory effect on weed growth and crop yield is selective and highly dependent on duration or term of sorgaab and sunfaag application.

Aqueous extracts of sorghum and sunflower are effective on weed growth but unfortunately might not be profitable enough in crop production; however, crop allelopathy can be manipulated for achieving sustainable weed management. Combination of phytotoxic crop water extracts with lower rates of herbicides may provide reduced weed control levels with reduced herbicide usage. The interesting review of allelopathic crop plants in weed management strategy is presented in reference [23]. Two field studies were conducted utilizing water extracts of sorghum, sunflower and rapeseed (Brassica napus L.) with reduced glyphosate dosage for controlling purple nutsedge (Cyperus rotundus L) in cotton [24]. Sorghum and rapeseed water extracts were tank mixed (at 15 or $18 \mathrm{~L} \mathrm{ha}^{-1}$ ) in different combinations with reduced rates of glyphosate by 767 and $575 \mathrm{~g}$ active substance (a.s.) ha ${ }^{-1}$ and sprayed as directed post emergence at 21 DAS. Purple nutsedge density and dry weight were suppressed by $78 \%$ to $95 \%$ and $83 \%$ to $95 \%$, respectively, when different crop water extracts were used in combination with a reduced rate of glyphosate. Seed cotton yield was improved from $15-21 \%$ in sorgaab and rape water extract combinations with reduced rates of glyphosate $(67-75 \%)$. Similar research has been conducted on water extracts of sorghum with sunflower in combination with herbicides in wheat, soybean, rice, and canola (Brassica sp.) [25, 26]. Both extracts, in combination with herbicides, have the same or even better effect on inhibition of growth of the following weeds: littleseed canarygrass and lesser swinecress, compared to single synthetic herbicide applications $[25,26]$. Spraying of wheat seedlings 30 DAS with sorgaab+sunfaag (18 L each ha ${ }^{-1}$ ) with mesosulfuron+idosulfuron (4.32 $\mathrm{g}^{\text {a.s. }}$ ha $\left.^{-1}\right)$ has the same effect on total weed density (reduction up to $90 \%$ in relation to control) as application of mesosulfuron+idosulfuron used alone, but with higher doses (120 g a.s. ha-1 $)$. Herbicidal solution has also improved yield parameters, both in relation to control and in relation to single herbicide application: fertile tillers (10\%), spikelets per spike (11\%) and grains per spike (10\%) [26]. In cotton, application of both extracts at $18 \mathrm{~L} \mathrm{ha}^{-1}$ each with glyphosate $\left(767 \mathrm{~g}\right.$ a.s. ha- $\left.{ }^{-1}\right) 21$ DAS has been the most effective in density reduction of the highly competitive weed purple nutsedge up to $93 \%$ [24]. However, the greatest benefit in wheat is the usage of a sorgaab/sunfaag combination which lowered by $70 \%$ doses of metribuzin and phenaxaprop (at $57 \mathrm{~g}$ a.s. ha $\mathrm{h}^{-1}$ ), applied at $18 \mathrm{~L}$ each ha ${ }^{-1}$. In turn, in cotton, application of the same rates of extracts per ha with glyphosate $(767 \mathrm{~g}$ a.s. ha ${ }^{-1}$ ) seems to be the most economically reasonable costs of following weed management method [24, 25].

Selectivity of plant extracts on weeds without any negative implications on crop productivity is probably due to differences in the physiological stage of plants and following plant compe- 
tition. Sunfaag has been applied when wheat seedlings were 3-4 weeks old while lambsquarters and toothed dock 1-week old at the stage of three to four leaf [20, 21].

High allelopathic potential conditioned by glucosinolates and isothiocyanates is present in Brassica sp. [27, 28]. Isothiocyanates have been strong suppressants of germination of spiny sowthistle (Sonchus asper L. Hill), scentless mayweed (Matricaria inodora L.), smooth pigweed (Amaranthus hybridus L.), barnyardgrass, blackgrass (Alopecurus myosuroides Huds.) and wheat [28]. Black mustard (Brassica nigra L.) extract of different plant parts like leaf, stem, flower and root have inhibited germination and radicle length of wild oat. Inhibitory effects on germination increased with increasing concentration of extract solution of the fresh plant parts [29]. Some experiments were conducted also using garden radish (Raphanus sativus L.) extract on germination of 25 weed and 32 crop species [30]. Garden radish extracts totally inhibited germination of 11 weeds such as Johnsongrass (Sorghum halelense L. Pers.), Alhagi spp., blackgrass (Alopecurus myosuroides Huds.), shepherd's-purse (Capsella bursa-pastoris L. Medik.), field bindweed (Convolvulus arvensis L.), dodder (Cuscuta sp.), carrot (Daucus carota L.), shortpod mustard (Hirschfeldia incana L.), Ochtodium aegyptiacum (L.), and shortfruit hedgemustard (Sisymbrium polyceratium L.), and 4 crop species namely lettuce (Lactuca sativa L.), tobacco (Nicotiana tabacum L.), bean (Phaseolus vulgaris L.), and clover (Trifolium sp.). Garden radish extracts at different rates $(100,66,50$ and $33 \%$ of pure extract) did not affect germination of wheat, cotton, and maize (Zea mays L.), but affected soybean germination at the $100 \%$ extract rate in vitro. Rhizome regeneration of Johnsongrass was inhibited by $54-99 \%$ depending on extract concentration. Regeneration of bermudagrass (Cynodon dactylon L. Pers.) rhizomes was inhibited to a lower extent at all concentrations; for instance, $54 \%$ inhibition occurred at the highest extract concentration. Lower extract rates stimulated redroot pigweed germination, while 66 and $100 \%$ extracts inhibited germination by 21 and $42 \%$, respectively. Inhibition reached only 56 and $49 \%$ at the highest extract concentration for common purslane (Portulaca oleracea L.) and cocklebur (Xanthium strumarium L.), respectively. Garden radish residues which were cut into pieces and incorporated into the growing medium decreased weed intensity and increased maize yield [31].

Legumes crops may also be applied as a source of allelochemicals useful in weed suppression. Mulch of dead pea plants could be used to control growth of weeds. Pea cover crop has regulated germination and growth of lady's thumb (Polygonum persicaria L.), smooth pigweed, smallflower galinsoga, and common lambsquarters. Similarly, the aqueous leachates (1\%) of all four legumes, velvetbean (Mucuna deeringiana (Bort.) Merr.), jackbean (Canavalia ensiformis (L.) DC.), jumbiebean (Leucaena leucocephala (Lam.) de Wit), and wild tamarind (Lysiloma latisiliquum (L.) Benth.), have been shown to suppress weeds [32]. These plants exhibited strong phytotoxic effects on the radicle growth of barnyardgrass, alegría (Amaranthus ssp.) and amaranth (Amaranthus hypochondriacus L.) [33]. Russian knapweed (Acroptilon repens) control is difficult in many crops. Allelopathic effects of extracts and plant parts of alfalfa (Medicago sativa L.) on Russian knapweed were reported both in Petri dishes and pot experiments [34]. Alfalfa has been recommended in fields with high mugwort (Artemisia vulgaris L.) infestation, as it decreased mugwort to $89 \%$ under field conditions, while extracts of alfalfa vegetative parts inhibited mugwort germination up to $83 \%$ in Petri dish assays. 
Application of plant extracts as pre-emergence or as early post emergence herbicides resulted in reduction of doses of synthetic herbicide due to their synergistic or additive action. However, not all phytotoxic extracts are effective enough to inhibit weed growth or germination when applied as spray even when plants show high allelopathic potential as mulch, intercropping system or in rotation. This may be the result of masking the activity of one compound by another in water solution or other factors such as impossibility of extract penetration through the cuticle [12]. A new opportunity to enhance effectiveness of usage of bioherbicides based on natural extracts is associated with extraction of individual allelochemicals and/or its comparison with synthetic herbicides. The extraction of sesquiterpene lactone, dehydrozaluzanin C (DHZ) produced among Compositae family serves as an example [34]. Comparison studies of isolated DHZ $(1 \mathrm{mM})$ and the commercial herbicide Logran ${ }^{\circledR}$ showed high inhibitory activity of DHZ on dicotyledonous plants while the synthetic herbicide showed no activity [34]. Also pure 2-benzoxazolinone (BOA) isolated from several graminaceous crops such as rye (Secale cereale L.), maize and wheat was active similarly as herbicide but its stability in the environment was much shorter than the synthetic herbicide [35].

\section{Plant allelopathins as sources of bioherbicides}

Plant phytotoxic extracts, after evaluation, can be successfully used in integrated weed management. However, as was aforementioned, not all systems of its application under field conditions are suitable and profitable enough. To circumvent masking effects of one allelopathin by another in plant extract, research is now focused on isolation and application of a single, specific compound for the purpose of weed elimination. The list of allelochemicals isolated from various plants that may act as inhibitors of weed seed germination and/or weed growth are summarized in Table 1. A purified allelopathic compound may act on target plants with much higher or much lower strength. Even in situations when an allelopathin is active at unprofitably high doses but has a favorable environmental profile, it still may be a source to explore due to several reasons such as biodegradability. Modifications of chemical structure can make a compound more active on target plants while preserving desire properties.

Herein, examples of purified allelopathins with possible roles as herbicides are described. Some herbicides based on modified allelopathins already launched on the market are also included.

\subsection{Sorgoleone}

The inhibitory effect of sorghum on various plant species has been known for many years. Accumulation of sorghum phytotoxins in soil affects crop growth and imposes the need for a crop rotation system. Besides crops, weeds are also vulnerable to its allelopathic influence [16, 36]. Sorghum toxicity is mainly determined by both hydrophilic phenols in herbage, as well as hydrophobic sorgoleone and its analogs exuded by the root hairs [37, 38]. Therefore, sorghum herbage reach can be successfully used against weeds as a foliar spray as it is discussed in detail in the previous chapter. 


\begin{tabular}{|c|c|c|}
\hline Compounds & Botanical source & Sensitive weeds \\
\hline $\begin{array}{l}\text { Glucosinolates, } \\
\text { Isothiocyanates }\end{array}$ & $\begin{array}{l}\text { mustard (Brassica sp.) } \\
\text { garden radish (Raphanus sativus) }\end{array}$ & $\begin{array}{l}\text { spiny sowthistle (Sonchus asper L. Hill), scentless } \\
\text { mayweed (Matricaria inodora L.), smooth pigweed } \\
\text { (Amaranthus hybridus L.), barnyardgrass (Echinochloa } \\
\text { cruss-galli L. Beauv.), slender meadow foxtail or } \\
\text { blackgrass (Alopecurus myosuroides Huds.), Alhagi spp., } \\
\text { Cachia maritime, Shepherd's-purse(Capsella bursa- } \\
\text { pastoris L.), morning glory (Convolvulus arvensis L.), } \\
\text { dodders (Cuscuta spp.), wild carrot or bird's nest } \\
\text { (Daucus carota L.), shortpod mustard, buchanweed or } \\
\text { hoary mustard(Hirschfeldia incana L.), Ochtodium } \\
\text { aegyptiacum (L.), shortfruit hedgemustard (Sisymbrium } \\
\text { polyceratium L.) }\end{array}$ \\
\hline Sorgoleone & $\begin{array}{l}\text { sorghum (Sorghum bicolor L. } \\
\text { Moench) }\end{array}$ & $\begin{array}{l}\text { littleseed canarygrass (Phalaris minor Retz.), lesser } \\
\text { swinecress (Coronopus didymus L.), purple nutsedge } \\
\text { (Cyperus rotundus L.), black nightshade (Solanum } \\
\text { nigrum L.), redroot pigweed (Amaranthus retroflexus L.), } \\
\text { common ragweed (Ambrosia atrtemisiflora L.), sicklepod } \\
\text { (Cassia obtusifolia L.) }\end{array}$ \\
\hline Momilactone & $\begin{array}{l}\text { rice (Oryza sativa L.), moss (Hypnum } \\
\text { plumaeform) }\end{array}$ & $\begin{array}{l}\text { barnyardgrass, (Echinochloa colonum L.), livid } \\
\text { amaranth(Amaranthus lividus L.), hairy crabgrass } \\
\text { (Digitaria sanguinalis L.), annual meadow grass, annual } \\
\text { bluegrass or poa (Poa annua L.) }\end{array}$ \\
\hline Artemisinin & $\begin{array}{l}\text { annual wormwood (Artemisia } \\
\text { annua L.) }\end{array}$ & $\begin{array}{l}\text { redroot pigweed, pitted morning-glory (Ipomoea } \\
\text { lacunose L.), common purslane (Portulaca oleracea L.), } \\
\text { annual wormwood, duckweed (Lemna minor L.), algae } \\
\text { (Pseudokirchneriella subcapitata) }\end{array}$ \\
\hline Leptospermone & $\begin{array}{l}\text { bottle brush (Callistemon citrinus), } \\
\text { manuka (Leptospermum scoparium } \\
\text { J.R., G. Forst) }\end{array}$ & $\begin{array}{l}\text { barnyard grass, hairy crabgrass, yellow foxtail (Setaria } \\
\text { glauca L.), california red oat (Avena sativa L.), Indian } \\
\text { mustard (Brassica juncea L.), curly dock (Rumex crispus } \\
\text { L.) }\end{array}$ \\
\hline Essential oils & eucalyptus (Eucalyptus sp.) & $\begin{array}{l}\text { barnyard grass, Cassia occidentalis, annual ryegrass } \\
\text { (Lolium rigidum) }\end{array}$ \\
\hline Sarmentine & pepper (Piper sp.) & $\begin{array}{l}\text { barnyard grass, redroot pigweed, crabgrass, } \\
\text { Sprangletop (Leptochloa filiformis Lam.), dandelion } \\
\text { (Taraxacum sp.), lambsquarter or wild spinach } \\
\text { (Chenopodium album L.), annual bluegrass or poa, } \\
\text { morning glory or bindweed, wild mustard, curly dock }\end{array}$ \\
\hline
\end{tabular}

Table 1. Allelopathic compounds isolated from plants that exhibit inhibitory potential on seed germination and growth of weeds 
However, allelochemical sorgoleone has enormous potential as an herbicide due to its high activity against various weed species. Studies conducted under laboratory conditions have shown that low doses of sorgoleone $(100 \mu \mathrm{M})$ inhibit growth of the following weeds by $80 \%$, black nightshade (Solanum nigrum L.), redroot pigweed, common ragweed ( $\mathrm{Am}$ brosia atrtemisiflora L.), and by $40 \%$ of sicklepod (Cassia obtusifolia L.), hairy crabgrass (Digitaria sanguinalis L.), velvetleaf (Abutilon theophrasti Medik.), barnyardgrass and tef (Eragrostis tef Zucc., Trotter) [11, 16].

Sorgoleone released into the soil may act as a pre-emergence herbicide. Its persistence in the soil during or after sorghum cultivation inhibits germination and growth of small-seeded weeds, e.g. hairy crabgrass and green bristlegrass (Setaria viridis (L.) Beauv.), due to its better absorption and translocation within the small seeds than in large seeds [39]. However, strength and final effect on seeds or seedling physiology is multifactor-dependent. Sorgoleone sorbs strongly to the organic matter. This allows an extended persistence in the soil but unfortunately, significantly reduces its bioavailability. Moreover, the dynamics of decomposition significantly influences sorgoleone bioactivity, e.g. the methoxy- group of the aromatic ring is decomposed by $26 \% 48 \mathrm{~h}$ after exudation; however, some amounts of sorgoleone are also extractable after 6 weeks [40,41]. Nevertheless, constitutive production of the compound allows a continuous supply and accumulation in the soil around $1.5 \mathrm{~cm}$ of root zone [42].

Inhibition of $\mathrm{H}^{+}$-ATPase in plant roots makes sorgoleone an effective growth inhibitor and potential post-emergence herbicide [43]. Decreased activity of that enzyme affects ion uptake and water balance by decreasing water uptake and affecting plant growth. Redroot pigweed, Jimson weed (Datura stramonium L.) and tef grown in hydroponic culture with $10 \mu \mathrm{M}$ sorgoleone were characterized by lower $\mathrm{H}^{+}$-ATPase activity in roots. Presence of sorgoleone in nutrient solution significantly suppressed growth and evoked brown coloration and necrosis $[43,44]$.

Sorgoleone may be taken up by roots but cannot be translocated acropetally by xylem due to high lipophilic properties. Therefore, its application as a post-emergence herbicide may be limited. However, as a spray $\left(0.6 \mathrm{~kg} \mathrm{ha}^{-1}\right)$, it has inhibited growth by $12 \%$ of green foxtail (Setaria faberi Herrm.), by $40-50 \%$ purslane, hairy crabgrass and velvetleaf, and up to $80-90 \%$ of common ragweed, redroot pigweed, and black nightshade [40].

Due to the structural similarity of sorgoleone to plastoquinon, it acts as a photosystem II (PSII) inhibitor $[11,43]$. It binds to the niche of the D1 protein in PSII, gathers electrons and does not allow reoxidation of plastoquinon A by the secondary electron acceptor, plastoquinone B. Competition studies under sorgoleone versus synthetic herbicides such as atrazine, diuron, metribuzin and bentazon have shown that sorgoleone is an atrazine competitive inhibitor [11, 12]. Moreover, the $I_{50}$ of sorgoleone is $0.1 \mu \mathrm{M}$ and similar to other PSII inhibitors. It is worth mentioning that sorgoleone belongs to the His215 family of PSII inhibitors, while atrazine belongs to Ser264. Mutation in Ser264 of the D1 protein is responsible for resistance to triazines as well as other non-triazine herbicides, leading to cross-resistance. However, plants resistant to atrazine, with a QB binding site on PSII mutation (Ser264), are not resistant to sorgoleone. Application of sorgoleone is particularly justified in the case of triazine-resistant biotypes of redroot pigweed, due to the same 
physiological effects as applications of atrazine in redroot pigweed-susceptible biotypes [11]. These properties make sorgoleone a potential early post-emergence herbicide when applied as a spray with much less environmental implications than atrazine. Therefore, inhibition of photosynthesis is the main target site of sorgoleone action in young seedlings but its mode of action in older plants may be different [12]. Sorgoleone can be a useful inhibitor of $p$-hydroxyphenylpyruvate dioxygenase (HPPD), which takes part in $\alpha$ tocopherol and plastoquinone synthesis. Inhibition of that enzyme leads to a decreased pool of available plastoquinone and indirectly affects activity of phytoene desaturase, a key enzyme in carotenoid synthesis. Such sequence of events causes declining carotenoid levels and affects photosynthesis [45]. Currently used triketone herbicides (e.g. sulcotrione, isoxaflutole) have the same mechanism of action on HPPD as sorgoleone, irreversible competitive inhibition, with $\mathrm{I}_{50}=0.4 \mu \mathrm{M}$. Triketone herbicides are considered by the U.S. Environmental Protection Agency (EPA) to be a low environmental risk. They are usually utilized as selective herbicides to eliminate broadleaf weeds in corn [10]. It follows, due to similar action and chemical structure and environmental friendly profile, sorgoleone might also be useful as a selective herbicide; however, such comparison studies have yet to be conducted. Then, its mode of action also cannot explain whether it is more or less active on broadleaf or grass weeds species [44].

\subsection{Momilactones}

Extracts and residues of rice, the well-known cereal plant, also have allelopathic potential. Among isolated secondary metabolites, phenolic acids, hydroxamic acids, fatty acids, terpenes and indoles were identified [46]. The key role in rice allelopathy plays momilactone A and B isolated from root exudates. High allelopathic rice varieties release up to 2-3 $\mu \mathrm{g}$ of momilactone B per day [3]. These compounds inhibited the growth of typical weeds in rice, e.g. barnyard grass and awnless barnyard grass (Echinochloa colona (L.) Link.) at concentrations higher than $1 \mu \mathrm{M}$ and $10 \mu \mathrm{M}$, respectively. Furthermore, phytotoxic abilities of momilacton A and B were also demonstrated on livid pigweed (Amaranthus lividus L.), hairy crabgrass and annual bluegrass (Poa annua L.) at concentrations higher than $60 \mu \mathrm{M}$ and $12 \mu \mathrm{M}$, respectively [47]. The experiment has shown that momilactone $\mathrm{B}$ is secreted by rice roots into the rhizosphere over the entire life cycle [48]. Momilactone A and B belong to the diterpenoid phytoalexins which are known as antimicrobial secondary metabolites generated in response to signal molecules called elicitors (especially biotic elicitors) [49]. Both compounds thought to be unique to rice, recently have been found in the moss (Hypnum plumaeforme Wils.), a taxonomically distinct plant [49]. Despite the ability of momilactone A and B to inhibit plant growth, its mode of action in plants is still unknown.

\subsection{Artemisinin}

Artemisinin is a sesquiterpenoid lactone of annual wormwood (Artemisia annua L.). It is synthesized and sequestered in glandular trichomes located on the leaves and flowers [51]. It can also be excreted by the roots or root hairs, but only at the beginning of the growing season; therefore, dead leaves are the major source of artemisinin in soils [52]. Artemisinin is also lost 
from annual wormwood by rain runoff but to a minor degree $(<0.5 \%)$, This allelopathin is well known as a promising anti-malaric agent but also as a phytotoxin selective mainly to broadleaf weeds. Artemisinin (at $33 \mu \mathrm{M}$ ) significantly reduced shoot and root growth of lettuce, redroot pigweed, pitted morning-glory (Ipomoea lacunose L.) common purslane and annual wormwood [53]. However, the same treatment had no effect on sorghum or velvetleaf. Several studies have been aimed at identifying the molecular target site of this compound as well as the structural requirements for herbicidal activity [53-55].The effect of artemisinin is most evident on root growth and chlorophyll content. In onion root tips, artemisinin $(10-100 \mu \mathrm{M})$ decreased the mitotic index, provoked abnormal mitotic figures and caused structural modifications of chromosomes [55]. However, no definite target site has yet been identified. The most recent studies on rice sprayed with $1.86 \mu \mathrm{M}$ artemisinin indicated its inhibiting abilities on photosynthetic electron transport [56]. Artemisinin site of action is probably plastoquinone B in photosystem II. Interestingly, as authors suggest, this effect is caused not directly by artemisinin itself, but rather by an unidentified artemisinin-metabolite occured in the plant after artemisinin application [56].

Other controversies around the phytotoxic potential of artemisinin arose when the dichloromethane extracts of annual wormwood leaves containing artemisinin showed a stronger phytotoxic effect on redroot pigweed seed germination and seedling growth than pure artemisinin [57]. Moreover, aqueous extract with disposed artemisinin had equal inhibitory effects on both physiological processes as allelopathin alone. This experiment suggests a marginal role of artemisinin in plant extract and joint action of other allelochemicals. Although, most studies analyzing allelopathic weed-crop interferences using annual wormwood were conducted under laboratory and greenhouse conditions [58].

Toxic studies on duckweed (Lemna minor L.) and the fresh water algae Pseudokirchneriella subcapitata (Korshikov) had $\mathrm{EC}_{50}$ values 0.24 and $0.19 \mathrm{mg} \mathrm{L}^{-1}$ respectively, with growth rate as endpoint corresponding to those of the herbicide atrazine [59]. These profiles questioned environmental safety of artemisinin for the purpose as a bioherbicide. It may be a result of its complex chemical structure, but this compound may be used as the basis for a new herbicide, based on artemisinin chemical structure. Such attempts have already been made using artemisinin's analogues [55]. Four of the tested 12 analogues inhibited germination and root growth of lettuce, Arabidopsis thaliana (L.) and duckweed at extremely low concentrations $(3 \mu \mathrm{M})$.

\subsection{Leptospermone}

Leptospermone (1-hydroxy-2-isovaloryl-4,4,6,6-tetramethyl cyclohexen-3,5-dione) is a natural triketone produced by the roots of the bottlebrush (Callistemon citrinus Curtis) [60]. In its pure form, it was tested both pre- and post-emergence on a range of plant species including: hairy crabgrass, yellow foxtail (Setaria glauca (L.) P. Beauv.), barnyard grass, California red oat (Avena sativa L.), redroot pigweed, Indian mustard (Brassica juncea L.) and curly dock (Rumex crispus L.). Leptospermone is a strong $\mathrm{p}$ - hydroxyphenylpyruvate dioxygenase (HPPD) inhibitor with $I_{50}$ values $3 \mu \mathrm{g} \mathrm{mL} \mathrm{m}^{-1}[61]$. Inhibition of this enzyme leads to disruption in carotenoid biosynthesis and loss of chlorophyll. Unfortunately, a pure compound rate of $9000 \mathrm{~g}$ a.s. ha-1 was required 
to give acceptable weed control. Such high doses excluded leptospermone from commercial development. The structure of this allelochemical was used as a basis for development of synthetic analogues including mesotrione (trade name Callisto), an herbicide produced by Syngenta AG. Mesotrione is applied for control of broadleaved weeds in maize. The rates of mesotrione are in the range from 75 to $225 \mathrm{~g}$ a.s. ha-1 (around 100 times more potent than leptospermone) [60].

However, leptospermone has lately been found as the main herbicidal component of manuka oil (Leptospermum scoparium J.R., G. Forst) [61]. Manuka oil (1\%) applied as post-emergence spray, significantly decreased growth and dry weight of redroot pigweed, barnyardgrass, velvetleaf and hairy crabgrass. Though, hairy crabgrass seedlings that emerged after manuka oil application were totally blanched. Pre-emergence application of $0.17 \%$ manuka oil which corresponds to $0.2 \mathrm{~L} \mathrm{ha}^{-1}$ of leptospermone inhibited hairy crabgrass growth by $50 \%$. The preemergence effects are mainly dependent on its persistence in soil. Average time of leptospermone half-life in soil was calculated at 15 days while applied as a compound of manuka oil time extended by 3 days. This clearly shows that half-life of active compounds may be longer in mixture than applied alone due to additive or synergistic action. This type of leptospermone application poses another possibility of usage for this compound in its natural form without chemical modification of the structure [61].

\subsection{Essential oils}

Lately, there has been a growing interest for using essential oils as allelopathins with bioherbicide potential. Some of them have already been commercialized and successfully launched in organic agriculture. They disrupt the cuticle and contribute to desiccation or burn down young tissues. Examples of this are the commercially available bioherbicide with the trade name of GreenMatch EX which consists of lemongrass (Cymbopogon sp.) oils or Interceptor ${ }^{\mathrm{TM}}$ with $10 \%$ pine (Pinus sylvestris L.) oil [3]. Essential oils are complex mixtures of monoterpenes, sesquiterpenes, and aromatic phenols, oxides, ethers, alcohols, esters, aldehydes and ketones [62]. The main terpenoids of volatile essential oils are monoterpenes (C10) and sesquiterpenes (C15). It has been well documented that essential oils found in foliage of eucalyptus (Eucalyptus sp.) show phytotoxic potential. During field experiments it has been reported that common weeds such as coffee senna (Cassia occidentalis L.) and barnyardgrass sprayed with different concentrations of eucalyptus oil (from $5 \%$ to $10 \% \mathrm{v} / \mathrm{v}$ with $0.05 \% \mathrm{v} / \mathrm{v}$ Tween-80) exhibited dose-dependent and species-dependent levels of injury. Coffee senna plants were more sensitive to the eucalyptus oil than barnyardgrass [62]. Phytotoxicity of eucalyptus oil is due to the components such as 1,8-cineole, citronellal, citronellol, citronellyl acetate, p-cymene, eucamalol, limonene, linalool, $\alpha$-pinene, $\gamma$-terpinene, $\alpha$-terpineol, alloocimene, and aromadendrene [62]. Pre-emergence herbicidal activity of 1,8-cineole 3, and 1,4-cineole 4 were tested against rigid ryegrass and garden radish var. Long Scarlet in laboratory-based bioassays. 1,8cineole and its derivatives showed a dose-dependent herbicidal activity against both weed species [64]. Laboratory studies [64, 65] also have shown that soil-applied 1,8-cineole suppressed the growth of several weeds. However, field reports demonstrated that 1,8-cineole alone has poor herbicidal activity $[67,68]$. The commercial herbicide cinmethylin is a 2-benzyl 
ether substituted analog of the monoterpene 1,4-cineole (1-methyl-4-(1-methylethyl)-7oxabicyclo heptane). This compound was discovered and partially developed by Shell Chemicals as a derivative of the allelopathic natural monoterpene, 1,8-cineole [69]. The benzyl ether substitution appears to decrease the volatility of the cineole ring by several orders of magnitude thereby rendering it more suitable for herbicide use [70]. Cinmethylin is a moderately effective growth inhibitor used for monocot weed control [71]. Despite the fact that it has been used commercially in both Europe and Japan and has been studied experimentally for several decades, the mechanism of action of this herbicide is still unknown [54, 72]. Cinmethylin was commercialized outside the United States in 1982 under the trade names of Cinch and Argold. Cinmethylin is active on several important grasses in rice; Echinochloa sp., Cyperus sp. and heartshape false pickerelweed (Monochoria viginalis Burm.f.) at rates from 25 to $100 \mathrm{~g}$ a.s. ha ${ }^{-1}[73]$.

\subsection{Sarmentine}

Sarmentine was first isolated from long pepper (Piper longum L.) fruits [74] but is also present in varied organs of other Piper species (Huang and Asolkan patent). It has been known as a medicinal plant with many beneficial multidirectional properties on human health. However, methanol extract of long pepper dry fruits has been shown to be suppressive to lettuce [75]. Purification and fractioning of long pepper crude extract allows the dissection of the active compound - sarmentine, a molecule with a long unsaturated fatty acid chain and pyrrolidine. Due to the hydrophobic properties, sarmentine is suspended with surfactants, $0.2 \%$ glycospere O-20, $2 \%$ ethanol and $0.1 \%$ sodium lauryl sulfate. As a foliar spray, it is active at $2.5 \mathrm{mg} \mathrm{mL}^{-1}$, but its high phytotoxicity is manifested at $5 \mathrm{mg} \mathrm{mL}^{-1}$. Higher concentrations of sarmentine caused almost 100\% mortality of redroot pigweed, barnyardgrass, bindweed (Convonvulus sp.), hairy crabgrass, sprangletop (Leptochloa sp.), annual bluegrass, wild mustard (Sinapis arvensis L.), curly dock with impaired effects on horseweed (Conyza canadensis (L.) Cronquist) and sedge (Carex sp.) growth under laboratory conditions. First phytotoxic symptoms such as bent stems and contact necrosis, have been visible 30 minutes after application; however fullblown implications were seen $7 \mathrm{~h}$ after spraying. The most likely mechanism of sarmentine action on plants is disruption of the plant cuticle which leads to disruption of cell membranes and lipid peroxidation followed by formation of radicals [76, 77].

As an herbicide, sarmentine and its derivatives may be both obtained from fruits of long pepper and successfully chemically synthesized [75]. Despite the fact that the compound is active under laboratory conditions, its chemical and biological instability under field conditions may limit its application as an herbicide. However, it has been shown that crucial for sarmentine herbicidal activity is the presence of an amine bond with a secondary amine. Replacement of the acid moiety with structurally similar fatty acids has not changed its phytotoxic potential. Moreover, natural herbicides based on sarmentine may also contain other derivatives with similar modes of action on plants but higher environmental stability [75]. Sarmentine may be successfully applied in combination with synthetic herbicides, e.g. aryloxyphenoxypropionic, benzoic acid, dicarboximide, organophosphorus, triazine, sulfonamide herbicides and with many others. This gives an 
opportunity to further the structural modification that makes the compound more stable without any disadvantages on bioherbicide action in plants. It is worth noting that sarmentine has already been patented as an herbicide but not commercialized yet [75].

\section{Biotechnology in bioherbicide investigation}

A lot of effort has been done to explore the nature of allelopathic interactions. Studies on allelopathic compounds greatly increased thanks to chemical and biochemical techniques, which improved identification and knowledge about its mode of action. Since then, the crucial role of secondary metabolites synthesized and released by plants became better understood. It has been clearly demonstrated that allelopathins may take part in very complex inter- and intra-specific ecological interactions including soil microorganisms. However, despite the extensive research carried out under laboratory conditions, the higher level of such interactions at the ecosystem level has not been sufficiently explored. Structure, chemical properties, and mode of action in plants of multitude allelochemicals are already known but, unfortunately, only a part-per thousand of them have been successfully introduced in agricultural practices. This is mainly due to limitations of compounds as plant protection agents but also due to extended field experiments. A very important aspect that allows the introduction of allelopathy to natural weed management is knowledge about biology of donor and target plants and the exact chemicals responsible for the interaction [78]. All formerly described limitations of natural compounds as bioherbicides decreasing in case of plant extracts as herbicides due to simple and low cost of application. However, separation of one, specific compound that is the most interesting for us among hundreds synthesized by plants often required information about its synthesis in vivo.

One of the problems is to obtain adequate amounts of the compound, when its chemical synthesis is impossible or collection of plants, unprofitable. Increased synthesis of an allelopathin gives triple profits. First of all, enhanced allelopathic potential of a plant makes it more competitive against weeds. Second of all, increased concentration of a compound makes plant extract more active. Thirdly, this allows collection of the compound at a sufficient amount and makes it more profitable. However, it is much easier to obtain active compounds from the crop species than wild living ones. Difficulties in introducing plants to cultivation are due to the low ability to grow outside their natural ecosystem [79].

Cells and organ cultures provide opportunities to circumvent these limitations. Abilities of undifferentiated and differentiated cells to produce allelochemicals may be commercialized in bioreactors using cell suspension cultures [79]. Such attempts have been made on Artemisia suspension culture for artemisinin production; however, obtained amounts of that compound were insufficient. The addition of $\beta$-cyclodextrins to the growing medium has increased artemisinin synthesis up to 300\% [80]. Allelochemicals produced by roots may be obtained from hairy root cultures, both via callogenesis or infection with Agrobacterium tumefaciens. Transgenic hairy roots are characterized by high genetic stability and facility to accumulate metabolites. The hairy root system already has been applied to increased production of 
phenolic compounds of nettleleaf goosefoot (Chenopodium murale Linn.) [81] and gossypol of cotton [82]. Active growth of roots and rapid colonization of the bioreactor allows rapidly reaching target weight, necessary to obtain an adequate quantity of the compound extracted from plants or growing medium.

The recombinant DNA technology can be useful to improve allelochemical production. Enhancing or suppression of gene expression, metabolic engineering and genetic transformation are promising new tools for allelochemical synthesis [79]. This approach is based on elucidation of the metabolic pathway, enzyme activities and identification of genes encoding crucial enzymes, associated with metabolite (allelochemical) synthesis.

Allelopathy is a quantitative trait. A genetic analysis of quantitative trait loci (QTL) is a promising approach to identify genes underlying this trait. Only a few crops are under genetic screening for its allelopathic properties including: rice, wheat, barley and oat [83, 84]. The first QTL map associated with allelopathic properties was developed in rice. A segregating population derived from a cross of two cultivars varying with allelopathic potential against barnyardgrass. The map contained 140 DNA markers with four main-effects QTL located on chromosome 2, 3 and 8 [85]. Proteomic studies on allelopathy of rice against barnyardgrass confirmed the crucial role of three enzymes: phenylalanine ammonia-lyse (PAL), thioredoxin and 3-hydroxy-3-methilglutarilcoenzyme A reductase 3 (HMGR) is highly involved in phenols biosynthesis [86]. Such a genetic approach may allow the location of the gene in the genome and better understanding of its function in plant allelopathy and create the chance of applying marker assisted selection (MAS) to enhance allelopathic abilities.

Just like breeding programs allow improved crop production, they may also improve production of allelopathic compounds increasing allelopathic potential.

Scopoletin has been known as allelopathic root exudates of oats (Avena sp.) that affects growth of neighboring plants. Screening of 3000 of Avena accessions has shown varying ability to scopoletin production. Twenty five of them have exuded higher amounts of scopoletin than control cultivar Garry, of which 4 were threefold more than the control [87]. Variation in allelopathin production was also discovered for sorgoleone of seven sorghum accessions [38] nomilacton A and B of 8 rice accessions [88] DIBOA and DIMBOA of 14 rye cultivars [88], gramine of 43 lines of modern cultivar of barley (Hordeum vulgare L.) and wild progenitor $H$. spontaneum (C. Koch) [90]. Enhanced production of active compounds from allelopathic plants can be developed by efficient breeding - selection of individuals with high allelopathic ability. Identification of a single gene, arranged in synthesis of allelopathin already has been performed for sorgoleone. SOR1 (or compatible SbDES3) expression is specific for root hairs of two species of sorghum (S. bicolor and S. halepense) and associated with sorgoleone synthesis, while it is not expressed in other organs of sorghum SOR1 encodes novel fatty acid desaturase (FAD), involved in the formation of a specific bond at 16:3 $\Delta^{9,12,15}$ pattern $[91,92]$. Comparative studies of FAD derived from sorghum with other desaturases showed high similarity to omega-3 fatty acid desaturases (FAD3) [93]. However, none of the hitherto known desaturases can synthesize double bonding at this unique pattern along the aliphathic chain of the sorgoleone molecule. Characterization of this gene allows an overexpression of SOR1 and increased sorgoleone synthesis and improved allelopathic potential of sorghum, as well as 
easier collection of the compound. Moreover, the well-known pathway of sorgoleone synthesis and characteristic of candidate genes may be a promising source of introducing sorgoleone production to grass crops [94].

The situation becomes more complicated when more than one gene encoding special enzymes is required to increase synthesis of a plant compound. Such difficulties have been encountered for DIBOA, synthesized by various grass species [95]. In maize, biosynthesis of this compound is determined by five genes ( $B \times 1$ to $B \times 5$ ) encoding three enzymes: tryptophan synthase $\alpha$ homolog, cytochrome P-450-dependent monooxygenase [95].

Monoterpenes are a large family of compounds produced by a varied family of aromatic plants. Some of the monoterpenes also take part in allelopathic interactions, e.g. linalool, cineole camphene, pinene, limonene, etc. Currently, metabolic engineering allows improved production of specific compounds in heterologous systems [96]. The most interesting are monoterpene synthases which catalyzed geranyl diphosphate (GPP) into output structure of numerous monoterpenes family, e.g. enhanced expression of limonene synthase in transgenic peppermint (Mentha piperita L.) has increased yield of monoterpenes. An alternative approach is to change the density of secretory structures by both plant hormone and transcriptional factors manipulation. Such attempts already have been made in annual wormwood and A. thaliana. It was recently found that the number of glandular trichomes increased in response to jasmonic acid. Spraying of annual wormwood with this hormone significantly increased density of these structures on leaves what was accompanied with higher artemisinin content [51]. This was an effect of enhanced expression of gene encoding enzymes taking part in artemisinin biosynthesis. On the other hand, in Arabidopsis, co-expression of two positive transcriptional factors (GL1, and R protein of maize) has significantly improved the number of trichomes [96].

However, we have to bear in mind that biosynthesis of natural compounds can be limited to organs, tissues or even cells. Specific locations of compound synthesis, accumulation or secretion often make that compound toxic to other tissues within the same plant organism. Moreover, even successful transformation of a plant does not guarantee successful and sufficient production of a desirable compound. The gene of (S)-linalool synthase (Lis) of fairy fans (Clarkia breweri Gray), constitutively expressed in transgenic petunia (Petunia hybrida Hook.), has produced linalool but in its glycosylated, non-volatile form [96].

All presented techniques provide greater knowledge on allelopathy. However, better understanding of such complex interactions among this phenomenon bring us one step forward to development of new strategies in weed management and finding new herbicides and new herbicidal target sites.

\section{Conclusions}

The phenomena of allelopathy and phytotoxic interactions between plants are strongly expanding branches of biological science. Allelochemicals, as a group of substances also called 
biocommunicators, seem to be a fruitful challenge for combining traditional agricultural practices and new approaches in pest management strategies. Allelochemicals have already been used to defend crops against pathogens, insects or nematodes, parallel to some attempts to use them for weed control. Crop rotation, cover crops, dead and living mulches are being employed in agriculture. Both in natural and agricultural ecosystems allelopathic interactions are involved in practically every aspect of plant growth, as they can play the role of stimulants and suppressants. Complex plant-plant and plant-microbe interactions in ecosystems and currently developing studies on molecular, cytological and physiological levels bring us to a better understanding of processes occurring around us. The ancient knowledge of well-known toxic properties of water extracts of a variety of allelopathic plants give us a basis that could be used in the creation of a novel approach in weed control.

Some allelochemicals, mainly these that are mentioned in the text above, may act as a starting point for production of new bioherbicides with novel target sites, not previously exploited, as the understanding of their mode of action is still growing. Creation of bioherbicides based on allelochemicals generates the opportunity to exploit natural compounds in plant protection and shows the possibility to cope with evolved weed resistance to herbicides. Despite the fact that we have extensive knowledge about the chemical nature of natural compounds, we can synthesize its analogues, and we have basically explored its phytotoxic potential, we still have insufficient data. Until recently, most studies on phytotoxicity have been conducted under laboratory conditions due to the ability to eliminate other environmental factors such us temperature, soil texture and its chemical and physical properties. Such approach allows the recognition of only direct effects of allelochemical action. There is still a great need to transfer laboratory data into field conditions. Such experiments are not willing to be taken on due to troublesome field experiments dependent on environmental conditions and a few year repetitions. New tools of molecular genetics, proteomics and metabolomics profiling as well as modern and sophisticated methods of chemistry and biochemistry will lead to the creation of substances, maybe based on the structure of particular compounds occurring in nature, which could be used without any risks as selective and eco-friendly herbicides.

\section{Author details}

Dorota Soltys $^{1 *}$, Urszula Krasuska ${ }^{1}$, Renata Bogatek ${ }^{2}$ and Agnieszka Gniazdowska ${ }^{2}$

*Address all correspondence to: d.soltys@ihar.edu.pl

1 Laboratory of Biotechnology, Plant Breeding and Acclimatization Institute - National Research Institute, Mlochow, Poland

2 Department of Plant Physiology, Warsaw University of Life Sciences - SGGW, Warsaw, Poland 


\section{References}

[1] Rola, H, Marczewska, K, \& Kucharski, M. Zjawisko odporności chwastów na herbicydy w uprawach rolniczych. Studia i Raporty IUNG-PIB (2007). , 8-29.

[2] International Survey of Herbicide Resistance Weedshttp://www.weedscience.org/ In.aspaccessed 31 October (2012).

[3] Dayan, F. E, Cantrell, C. L, \& Duke, S. O. Natural products in crop protection. Bioorganic \& Medicinal Chemistry (2009). , 17(12), 4022-4034.

[4] Gniazdowska, A, \& Bogatek, R. Alleopathic interaction between plants. Multiside action of allelochemicals. Acta Physiologiae Plantarum (2005). B) , 395-407.

[5] Soltys, D, Rudzinska-langwald, A, Gniazdowska, A, Wisniewska, A, \& Bogatek, R. Inhibition of tomato (Solanum lycopersicum L.) root growth by cyanamide is due to altered cell division, phytohormone balance and expansin gene expression. Planta (2012). , 236(5), 1629-1638.

[6] Weir, T. L, Park, S-W, \& Vivanco, J. M. Biochemical and physiological mechanisms mediated by allelochemicals. Current Opinion in Plant Biology (2004). , 7(4), 472-479.

[7] Iqbal, A, \& Fry, S. C. Potent endogenous allelopathic compounds in Lepidium sativum seed exudate: effects on epidermal cell growth in Amaranthus caudatus seedlings. Journal of Experimental Botany (2012). , 63(7), 2595-2604.

[8] Hussain, M. I, \& Reigosa, M. J. Allelochemical stress inhibits growth, leaf water relations, PSII photochemistry, non-photochemical fluorescence quenching, and heat energy dissipation in three C3 perennial species. Journal of Experimental Botany (2011). , 62(13), 4533-4545.

[9] Li, Z-H, Wang, Q, Ruan, X, Pan, C-D, \& Jiang, D-A. Phenolics and Plant Allelopathy Molecules (2010). doi:10.3390/molecules15128933, 15(12), 8933-8952.

[10] Vyvyan, W. R. Allelochemicals as leads for new herbicides and agrochemicals. Tetrahedron (2002). , 58(9), 1632-1646.

[11] Nimbal, C. I, Yerkes, C. N, Weston, L. A, \& Weller, S. C. Herbicidal activity and site of action of the natural product sorgoleone. Pesticide Biochemistry and Physiolology (1996). , 54(2), 73-83.

[12] Dayan, F. E, Howell, J, \& Widenhamer, J. D. Dynamic root exudation of sorgoleone and its in planta mechanism of action. Journal of Experimental Botany (2009). , 60(7), 2107-2117.

[13] Belz, R. G, Hurle, K, \& Duke, S. O. Dose-response- A challenge for allelopathy? Nonlinearity in Biology, Toxicology and Medicine (2005). , 3(2), 173-211. 
[14] Duke, S. O. Natural pesticides from plants. In: J. Janick and J.E. Simon (eds.) Advances in new crops. Portland: Timber Press; (1990). , 511-517.

[15] Dayan, F. E, Owens, D. K, \& Duke, S. O. Rationale for a natural products approach to herbicide discovery. Pest Management Science (2012). , 68(4), 519-528.

[16] Bhowmik, P. C. Inderjit. Challenges and opportunities in implementing allelopathy for natural weed management. Crop Protection (2003). , 22(4), 661-671.

[17] Irshad, A, \& Cheema, Z. A. (2005). Comparative efficacy of sorghum allelopathic potential for controlling barnyardgrass in rice. Proceedings of the $4^{\text {th }}$ World Congress on Allelopathy, Wagga Wagga, New South Wales, Australia. http://www.regional.org.au/au/allelopathy/2005/2/4/2220_irshada.htm

[18] Khaliq, A, Cheema, Z. A, Mukhtar, M. A, \& Ahmad, S. M. Evaluation of sorghum (Sorghum bicolor) water extract for weed control in soybean. International Journal of Agriculture and Biology (1999). , 1(1), 23-26.

[19] Cheema, Z. A, \& Khaliq, A. Use of sorghum allelopathic properties to control weeds in irrigated wheat in semi arid region of Punjab. Agriculture, Ecosystems \& Environment. (2000).

[20] Anjum, T, \& Bajwa, R. Field appraisal of herbicide potential of sunflower leaf extract against Rumex dentatus. Field Crops Research (2007).

[21] Anjum, T, \& Bajwa, R. The effect of sunflower lear extracts on Chenopodium album in wheat fields in Pakistan. Crop Protection (2007). , 26(9), 1390-1394.

[22] Naseem, M, Aslam, M, Ansar, M, \& Azhar, M. Allelopathic effects of sunflower water extract on weed control and wheat productivity. Pakistan Journal of Weed Science Research (2009). , 15(1), 107-116.

[23] Bhadoria PBSAllelopathy: a natural way towards weed management. American Journal of Experimental Agriculture (2011). , 1(1), 7-20.

[24] Iqbal, J, Cheema, Z. A, \& Mushtaq, M. Allelopathic crop water extracts reduce the herbicide dose for weed control in cotton (Gossypium hirsutum). International Journal of Agriculture and Biology (2009). , 11(4), 360-366.

[25] Razzaq, Z. A, Cheema, K, Jabran, K, Farooq, M, Khaliq, A, \& Haider, G. Basra SMA. Weed management in wheat through combination of allelopathic water extract with reduced doses of herbicides. Pakistan Journal of Weed Science Research (2010). , 16(3), 247-256.

[26] Razzaq, A, Cheema, Z. A, Jabran, K, Hussain, M, Farooq, M, \& Zafar, M. Reduced herbicide doses used together with allelopathic sorghum and sunflower water extracts for weed control in wheat. Journal of Plant Protection Research (2012). , 52(2), 281-285. 
[27] Fenwick, G. R, Heaney, R. K, \& Mullin, W. J. Glucosinolates and their breakdown products in food and food plants. Critical Reviews in Food Science and Nutrition (1983). , 18-123.

[28] Petersen, J, Belz, R, Walker, F, \& Hurle, K. (2001). Weed suppression by release of isothiocyanates from turnip-rape mulch. Agronomy Journal 2001;, 93(1), 37-43.

[29] Turk, M. A, \& Tawaha, A. M. Allelopathic effect of black mustard (Brassica nigra L.) on germination and growth of wild oat (Avena fatua L.). Crop Protection (2003). , 22(4), 673-677.

[30] Uygur, F. N, Koseli, F, \& Cinar, A. Die allelopathische Wirkung von Raphanus sativus L. Journal of Plant Diseases and Protection Zeitschrift für Pflanzenkrankheiten und Pflanzenschutz, Sonderheft (1990). XII , 259-264.

[31] Uludag, A, Uremis, I, Arslam, M, \& Gozcu, D. Allelopathy studies in weed science in Turkey- a review Journal of Plant Diseases and Protection Zeitschrift für Pflanzenkrankheiten und Pflanzenschutz Sonderheft (2006). XX , 419-426.

[32] Akemo, M. C, Regnier, E. E, \& Bennett, M. A. Weed suppression in spring-sown rye (Secale cereale)-pea (Pisum sativum) cover crop mixes. Weed Technology (2000). , 14(3), 545-549.

[33] Caamal-maldonado, J. A, Jiménez-osornio, J. J, Torres-barragán, A, \& Anaya, A. L. The use of allelopathic legume cover and mulch species for weed control in cropping systems. Agronomy Journal (2001). , 93(1), 27-36.

[34] Macías, F. A. Galino JCG, Molinillo JMG, Castellano D. Dehydrozaluzanin C: a potent plant growth regulator with potential use as a natural herbicide template. Phytochemistry (2000). , 54(2), 165-171.

[35] Reigosa, M. J, Gonzalez, L, Sanches-moreiras, A, Duran, B, Puime, D, Fernandez, D. A, \& Bolano, J. C. Comparison of physiological effects of allelochemicals and commercial herbicides. Allelopathy Journal (2001). , 8(2), 211-220.

[36] Alsaadawi, I. S, Al-ekeelie, M. H. S, \& Al-hamzawi, M. K. Differential allelopathic potential of grain sorghum genotypes to weeds. Allelopathy Journal (2007). , 19(1), 153-160.

[37] Lehle, F. R, \& Putman, A. R. Allelopathic potential of sorghum (Sorghum bicolor): isolation of seed germination inhibitors. Journal of Chemical Ecology (1983). , 9(8), 1223-1234.

[38] Czarnota, M. A, Rimando, A. M, \& Weston, L. A. Evaluation of root exudates of seven sorghum accessions. Journal of Chemical Ecology (2003). , 29(9), 2073-2083.

[39] Netzly, D. H, \& Butler, L. G. Roots of sorghum exude hydrophobic droplets containing biologically active components. Crop Science (1986). , 26(4), 775-778.

[40] Czarnota, M. A, Paul, R. N, Dayan, F. E, Nimbal, H. I, \& Weston, L. A. Mode of action, localization of production, chemical nature, and activity of sorgoleone: a potent 
PSII inhibitor in Sorghum spp. root exudates. Weed Technology (2001). , 15(4), 813-825.

[41] Weston, L. A, \& Czarnota, M. A. Activity and persistence of sorgoleone, a long-chain hydroquinone produced by Sorghum bicolor. Journal of Crop Production (2001). , $4(2), 363-377$.

[42] Trezzi, M. M, Vidal, R. A, \& Dick, D. P. Peralba MCR, Kruse ND. Sorptive behavior of sorgoleone in soil in two solvent systems and determination of its lipophilicity. Journal of Environmental Science and Health (2006). , 41(4), 345-356.

[43] Hejl, A. M, \& Koster, K. L. The allelochemical sorgoleone inhibits root $\mathrm{H}^{+}$-ATPase and water uptake. Journal of Chemical Ecology (2004). , 30(11), 2181-2191.

[44] Einhellig, F. A, \& Souza, I. F. Phytotoxicity of sorgoleone found in grain sorghum root exudates. Journal of Chemical Ecology (1992). , 18(1), 1-11.

[45] Meazza, G, Scheffler, B. E, Tellez, M. R, Rimando, A. M, Romagni, J. G, Duke, S. O, Nanayakkara, D, Khan, I. A, Abourashed, E. A, \& Dayan, F. E. The inhibitory activity of natural products on plant p-hydroxyphenylpyruvate dioxygenase. Phytochemistry (2002). , 59(3), 281-288.

[46] Kato-noguchi, H, Hasegawa, M, Ino, T, Ota, K, \& Kujime, H. Contribution of momilactone A and B to rice allelopathy. Journal of Plant Physiology (2010). , 167(10), 787-791.

[47] Chung, I-M, Hahn, S-J, \& Ahmad, A. Confirmation of potential herbicidal agents in hulls of rice, Oryza sativa. Journal of Chemical Ecology (2005). , 31(6), 1339-52.

[48] Kato-noguchi, H, Ota, K, \& Ino, T. Release of momilactone A and B from rice plants into the rhizosphere and its bioactivities. Allelopathy Journal (2008). , 22(2), 321-8.

[49] Okada, A, Okada, K, Miyamoto, K, Koga, J, Shibuya, N, Nojiri, H, \& Yamane, H. OsTGAP1, a bZIP transcription factor, coordinately regulates the inductive production of diterpenoid phytoalexins in rice. The Journal of Biological Chemistry (2009). , 284(39), 26510-26518.

[50] Kato-noguchi, H. Convergent or parallel molecular evolution of momilactone A and B: Potent allelochemicals, momilactones have been found only in rice and the moss Hypnum plumaeforme. Journal of Plant Physiology (2011). , 168-1511.

[51] Nguyen, K. T, Arseault, P. R, \& Wethers, P. J. Trichomes + roots + ROS = artemisinin: regulating artemisinin biosynthesis in Artemisia annua L. In Vitro Cellular and Developmental Biology- Plant (2011). , 47(3), 329-338.

[52] Jessing, K. K, Cedergreen, N, Mayer, P, Libous-bailey, L, Strobel, B. W, Rimando, A, \& Duke, S. O. Loss of artemisinin produced by Artemisia annua L. to the soil environment. Industrial Crops and Products. (2013). , 43-132. 
[53] Duke, S. O, Vaughn, K. C, Croom, E. M, \& Elsohly, H. N. (1987). Artemisinin, a constituent of annual wormwood (Artemisia annua) is a selective phytotoxin. Weed Science $1987 ;$, 35(4), 499-505.

[54] DiTomaso JMDuke SO. Is polyamine biosynthesis a possible site of action of cinmethylin and artemisinin? Pesticide Biochemistry and Physiology (1991). , 39(2), 158-167.

[55] Dayan, F. E, Hernandez, A, Allen, S. N, Moraces, R. M, Vroman, J. A, Avery, M. A, \& Duke, S. O. Comparative phytotoxicity of artimisinin and several sesquiterpene analogues. Phytochemistry (1999). , 50(4), 607-614.

[56] Bharati, A, Kar, M, \& Sabat, S. C. Artemisinin inhibits chloroplast electron transport activity: mode of action. PLOS ONE (2012). e38942. doi:10.1371/journal.pone. 0038942http://www.plosone.org/article/info\%3Adoi\%2F10.1371\%2Fjournal.pone. 0038942

[57] Lydon, J, Teasdale, J. R, \& Chen, P. K. Allelopathic activity of annual wormwood (Artemisia annua) and its role of artemisinin. Weed Science (1997). , 45-807.

[58] InderjitNilsen ET. Bioassays and field studies for allelopathy in terrestrial plants: progress and problems. Critical Reviews in Plant Sciences (2003).

[59] Jessing, K. K. Production of biomedicine under different climatic conditions- Artemisinin as study case IOP Conf. Series: Earth and Environmental Science 6 (2009). doi: 10.1088/http://iopscience.iop.org/1755-1315/6/34/342026/pdf/ 1755-1315_6_34_342026.pdf

[60] Cornes, D. (2006). Callisto: A very successful maize herbicide inspired by allelochemistry. Maize Association of Australia 6th Triennial Conference. http://www.regional.org.au/au/allelopathy/2005/2/7/2636_cornesd.htm

[61] Dayan, F. E, Howell, J. L, Marais, J. P, Ferreira, D, \& Koivunen, M. Manuka oil, a natural herbicide with preemergence activity. Weed Science (2011). , 59(4), 464-469.

[62] Batish, D. R, Singh, H. P, Kohli, R. K, \& Kaur, S. Eucalyptus essential oil as a natural pesticide. Forest Ecology and Management (2008). , 256(12), 2166-2174.

[63] Batish, D. R, Setia, N, Singh, H. P, \& Kohli, R. K. Phytotoxicity of lemon-scented eucalypt oil and its potential use as a bioherbicide. Crop Protection (2004). , 23(12), 1209-1214.

[64] Barton, A. F, Dell, B, \& Knight, A. R. Herbicidal activity of cineole derivatives. Journal of Agricultural and Food Chemistry 210;, 58(18), 10147-55.

[65] Vaughn, S. F, \& Spencer, G. F. Volatile monoterpenes as potential parent structures for new herbicides. Weed Science (1993). , 41(1), 114-119.

[66] Romagni, J. G, Allen, S. N, \& Dayan, F. E. Allelopathic effects of volatile cineoles on two weedy plant species. Journal of Chemical Ecology (2000). , 26(1), 303-313. 
[67] Halligan, J. P. Toxic terpenes from Artemisia californica. Ecology (1975). , 56(4), 999-1003.

[68] Heisey, R. M, \& Delwiche, C. C. Phytotoxic volatiles from Trichostema lanceolatum. American Journal of Botany (1984). , 71(6), 821-828.

[69] Grayson, B. T, Williams, K. S, Freehauf, P. A, Pease, R. R, Ziesel, W. T, Sereno, R. L, \& Reinsfelder, R. E. The physical and chemical properties of the herbicide cinmethylin. Pesticide Science (1987). , 21(2), 143-153.

[70] Vaughn, S. F, \& Spencer, G. F. Synthesis and herbicidal activity of modified monoterpenes structurally similar to cinmethylin. Weed Science (1996). , 44(1), 7-11.

[71] Russell, S. G, Monaco, T. J, \& Weber, J. B. Influence of soil moisture on phytotoxicity of cinmethylin to various crops. Weed Science (1991). , 39(3), 402-407.

[72] Baum, S. F, Karanastasis, L, \& Rost, T. L. Morphogenetic effect of the herbicide Cinch on Arabidopsis thaliana root development. Journal of Plant Growth Regulation (1998). , 17(2), 107-114.

[73] Duke, S. O. Allelopathy: Current status of research and the future of the discipline: A commentary. Allelopathy Journal (2010). , 25(1), 17-30.

[74] Huang, H, Morgan, C. M, Asolkar, N. R, Koivunen, M. E, \& Marrone, P. G. Phytotoxicity of sarmentine isolated from long pepper (Piper longum) fruit. Journal of Agricultural and Food Chemistry (2010). , 58(18), 9994-10000.

[75] Huang, H, \& Asolkar, N. R. (2011). Use of sarmentine and its analogs for controlling plant pests. Patent Patentdocs: http://www.faqs.org/patents/accessed 27 January 2011).(20110021358)

[76] Fukuda, M, Tsujino, Y, Fujimori, T, Wakabayashi, K, \& Böger, P. Phytotoxic activity of middle-chain fatty acids I: effects on cell constituents. Pesticide Biochemistry and Physiolology (2004). , 80(3), 143-150.

[77] Lederer, B, Fujimori, T, Tsujino, Y, Wakabayashi, K, \& Böger, P. Phytotoxic activity of middle-chain fatty acids II: peroxidation and membrane effects. Pesticide Biochemistry and Physiolology (2004). , 80(3), 151-156.

[78] Macías, F. A, Molinillo, J. M, Varela, R. M, \& Galindo, J. C. Allelopathy--a natural alternative for weed control. Pest Management Science (2007). , 63(4), 327-48.

[79] Bourgaud, F, Gravot, A, Milesi, S, \& Gontier, E. Production of plant secondary metabolites: a historical perspective. Plant Science (2001). , 161(5), 839-851.

[80] Durante, M, Caretto, S, Quarta, A, De Paolis, A, Nisi, R, \& Mita, G. Cyclodextrins enhance artemisinin production in Artemisia annua suspension cell cultures. Applied Microbiology and Biotechnology (2011). , 90(6), 1905-1913.

[81] Mitic, N, Damitrovic, S, Djordjevic, M, Zdravkovic-korac, S, Nikolic, R, Raspora, M, Djordjevic, T, Maksimovic, V, Živkovic, S, Krstic-miloševic, D, Stanišic, M, \& Nin- 
kovic, S. Use of Chenopodium murale L. transgenic hairy root in vitro culture system as a new tool for allelopathic assays. Journal of Plant Physiology (2012). , 169(12), $1203-1211$.

[82] Triplett, B. A, Moss, S. C, Bland, J. M, \& Dowd, M. K. Induction of hairy root cultures from Gossypium hirsutum and Gossypium barbadense to produce gossypol and related compounds. In Vitro Cellular \& Developmental Biology- Plant (2008). , 44(6), 508-517.

[83] Olofsdotter, M, Jensen, L. B, \& Courtois, B. Improving crop competitive ability using allelopathy- an example from rice. Plant Breeding (2002). , 121(1), 1-9.

[84] Belz, R. G. Allelopathy in crop/weed interactions- an update. Pest Management Science (2007). , 63(4), 308-326.

[85] Jensen, L. B, Courtois, B, Shen, L, Li, Z, Olofsdotter, M, \& Mauleon, R. P. Locating genes controlling allelopathic effects against Echinochloa crus-galli (L.) in upland rice. Agricultural Journal (2001). , 93(1), 21-26.

[86] Lin, W-X, He, H-Q, Shen, L-H, Chen, X-X, Ke, Y, Guo, Y-C, \& He, H-B. A proteomic approach to analysing rice allelopathy on barnyard grass (Echinochloa crus-galli L.). $4^{\text {th }}$ International Crop Science Congress 26.(2004). Queensland, Australia. http:// www.cropscience.org.au/icsc2004/poster/2/4/1/1414_xionglw.htm, 08-1.

[87] Fay, P. K, \& Duke, W. B. An assessment of allelopathic potential in Avena germplasm. Weed Science (1977). , 25-224.

[88] Kato-noguchi, H. Allelopathic substance in rice root exudates: rediscovery of momilactone B as an allelochemical. Journal of Plant Physiology (2004). , 161(3), 271-276.

[89] Copaja, S. V, Villarroel, E, Bravo, H. R, Pizarro, L, \& Argandona, V. H. Hydroxamic acids in Secale cereale L. and the relationship with their antifeedant and allelopathic properties. Zeitschrift fuer Naturforschung Section C Journal of Biosciences (2006). , 61-670.

[90] Lovett, J. V. Hoult AHC. (1992). Gramine: the occurrence of a self defence chemical in barley, Hordeum vulgare L. In: Hutchinson KJ, Vickery PJ. (eds) Looking Back- Planning Ahead conference proceedings, February Australian Agronomy Conference. "'". Edited by Proceedings of the 6th Australian Agronomy Conference, 1992, The University of New England, Armidale, New South Wales. http:// www.regional.org.au/au/asa/1992/concurrent/alternative-practices-plant-protection/ p.htm\#TopOfPage, 10-14.

[91] Pan, Z, Rimando, A. M, Baerson, S. R, Fishbein, M, \& Duke, S. O. Functional characterization of desaturases involved in the formation of the terminal double bond of an unusual 16:3 $9,12,15$ fatty acid isolated from Sorghum bicolor root hairs. Journal of Biological Chemistry (2007). , 282(7), 4326-4335. 
[92] Yang, X, Scheffler, B. E, \& Weston, L. A. SOR1, a gene associated with bioherbicide production in sorghum root hairs. Journal of Experimental Botany (2004). , 55-2251.

[93] Yang, X, Owens, T. G, Scheffler, B. E, \& Weston, L. A. Manipulation of root hair development and sorgoleone production in sorghum seedlings. Journal of Chemical Ecology (2004). , 30(1), 199-213.

[94] Weston, L. A, \& Duke, S. O. Weed and crop allelopathy. Critical Reviews in Plant Sciences (2003).

[95] Frey, M, Chomet, P, Glawischnig, E, Stettner, C, Grün, S, Winklmair, A, Wolfgang, E, Bacher, A, Meeley, R. B, Briggs, S. P, Simcox, K, \& Gierl, A. Analysis of a chemical plant defense mechanism in grasses. Science (1997). , 277(3526), 696-699.

[96] Mahmoud, S. S, \& Croteau, R. B. Strategies for transgenic manipulation of monoterpene biosynthesis in plants. Trends in Plant Science (2002). , 7(8), 366-373. 